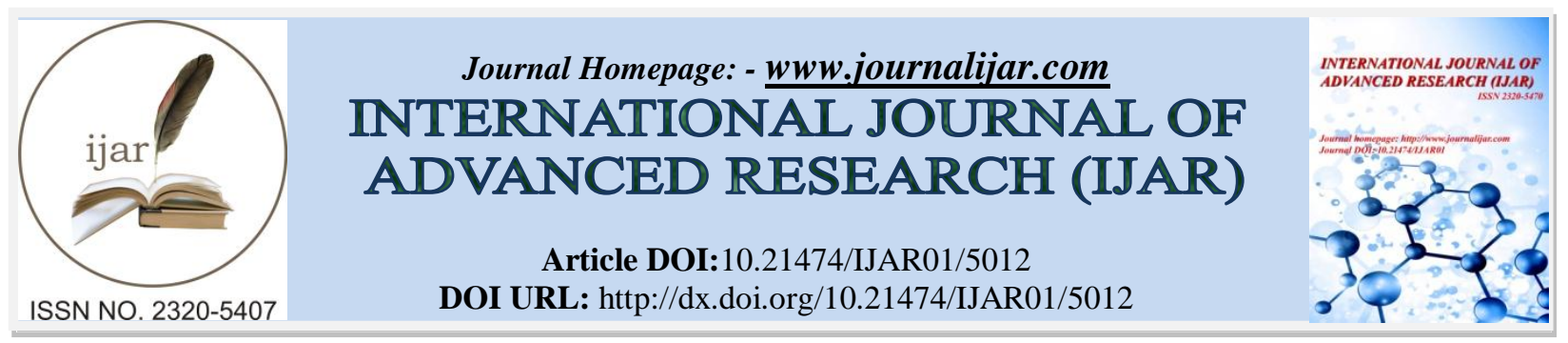

RESEARCH ARTICLE

\title{
MEASLES VIRUS N AND P PROTEINS FIND INTERACTING PARTNERS IN HELA CELLS.
}

Sankhajit Bhattacharjee, Rishi Kumar Jaiswal and Pramod Kumar Yadava.

Applied Molecular Biology Laboratory, School of life Sciences, Jawaharlal Nehru University, New Delhi-110067, India.

\section{Manuscript Info}

\section{Manuscript History}

Received: 28 May 2017

Final Accepted: 30 June 2017

Published: July 2017

Key words:-

Measles virus, Nucleocapsid Protein (N), Phosphoprotein (P), Pull Down Assay, HeLa cells.

\section{Abstract}

Measles, a contagious disease, is caused by measles virus with negative stranded non-segmented genome. The apoptotic property of $\mathrm{N}$ protein in human cancerous cell line is well established. Like any infectious agent, measles virus is expected to interact with certain molecules within the host cell in addition to surface receptors. We detected the binding partners of $\mathrm{N}$ and $\mathrm{P}$ proteins separately from cervical cancer cell line (HeLa) and checked by semi-quantitative real time PCR the gene expression affected by these interactions as well as the pathways with which the viral proteins interfere. Measles virus is an innately oncotropic virus. This interaction study by pull down assay will be helpful in elucidating their roles in cancer progression.

Copy Right, IJAR, 2017,. All rights reserved.

\section{Introduction:-}

Measles virus, the causative agent of measles belongs to the family of Paramyxoviridae and is placed under the genus Morbillivirus. It is an enveloped, pleomorphic, single-stranded RNA virus. The genome is non-segmented with a negative polarity. The RNA is 15894 nucleotides in length. Two receptors CD46 and SLAM/CD150 on host cell are reported for the entry of measles virus. The virus is oncotropic and oncolytic in nature.

The viral nucleocapsid protein ( $\mathrm{N}$ protein) in tightly associated with the measles virus RNA to form helical structure and confers stability to the genome by protecting it from degradation by nucleases ${ }^{1}$. It comprises of two domains: 1 ) NCORE: an N-terminal domain consisting of 1-400 amino acids and 2) NTAIL: a C-terminal domain consisting of 401-525 amino acids. The NCORE is responsible for RNA binding and self-assembly ${ }^{2}$. The NTAIL is associated with the formation of ribonucleoprotein (RNP) complex ${ }^{3}$. The NTAIL is proposed to interact with Hsp72, IRF3, FygRII and $\mathrm{NR}^{4-7}$.

The $\mathrm{P}$ gene encodes the phosphoprotein (P protein), which attaches with the nucleocapsid protected RNA complex to give rise to ribonucleoprotein (RNP) complex ${ }^{3}$. It also attaches with the large protein and thus remains as a part of RNA dependent RNA polymerase and acts as a cofactor. L protein recognizes RNP. The P protein can also be viewed as N-terminal domain (PNT) and C-terminal domain (PCT). The PCT is responsible for transcription, whereas genome replication requires both PNT and PCT. It is reported to be associated with the suppression of host immune system. It can also stimulate the degradation of STAT ${ }^{8}$. It can inhibit the phosphorylation of Jak $1^{9}$ as well as $\operatorname{STAT} 1^{10}$. 
$\mathrm{N}$ protein is repoted to be anti-apoptotic in nature and promotes lysis of cancer cells by syncytia formation ${ }^{11}$. So it is vital to check its interacting partners and the pathway that may be modulated by the viral protein. Here we also studied the interaction of host proteins with $\mathrm{P}$ protein. We have chosen HeLa cells for this study. It was observed that $\mathrm{N}$ and $\mathrm{P}$ interact with PTK2 and PI3K signaling pathways. This result may help us to elucidate the possible roles played by these proteins in cancer progression.

\section{Materials and Methods:-}

\section{Sub-cloning:-}

For expression of $\mathrm{N}$ and $\mathrm{P}$ proteins in bacterial system, both genes were sub-cloned in pET-28a+ from pCA-P (a kind gift from Prof. Martin Billeter). The forward and reverse primers used for $\mathrm{N}$ and $\mathrm{P}$ gene respectively were:

5'-CGTCATATGATGGCCACACTTTTAAGGAG-3' (Forward primer N)

5'-CGTCTCGAGCTAGTCTAGAAGATTTCTGT-3' (Reverse primer, N)

5'-ATTCATATGATGGCAGAAGAGCAGGCACG-3' (Forward primer P) and

5'-CGGCTCGAGCTACTTCATTATTATCTTCA-3'(Reverse primer P) respectively. Two restriction sites,

(NdeI and XhoI), were introduced upstream and downstream of P open reading frame (ORF) to generate pET-28a+N/P construct. For mammalian expression system the genes were cloned in pcDNA3.1 vector. The restriction sites used were XhoI and EcoRI. The forward and reverse primers for $\mathrm{N}$ and $\mathrm{P}$ were:

5'-ATACTCGAGATGGCCACACTTTTAAGGAG-3' (forward primer for N)

5'-ATAGAATTCGTCTAGAAGATTTCTGTCAT-3'(reverse primer for N)

5'-ATACTCGAGATGGCAGAAGAGCAGGCACG-3'(forward Primer for P)

5'-CGCGAATTCCTTCATTATTATCTTCATCA-3'(reverse primer for P) respectively.

\section{HeLa Cell Culture and Protein Isolation:-}

HeLa cells (a human cervical cancer cell line), was sub-cultured in T75 dish using complete DMEM media. The dish was incubated at $37^{\circ} \mathrm{C}$, in $5 \% \mathrm{CO} 2$ and humidified atmosphere. When the cells reached $90 \%$ confluency, the media was withdrawn from the T75 flask. The cells were washed with 1X PBS, trypnized, and harvested by centrifugation at $1,500 \mathrm{rpm}$ for 1.5 minutes. After discarding the supernatant the cells were rewashed with $1 \mathrm{X}$ PBS. The cells were incubated in lysis buffer [Tris-Cl pH $7.4(50 \mathrm{mM}), \mathrm{NaCl}(150 \mathrm{mM})$, EDTA pH 8.0 (1 mM), IGEPAL-CA-630 (1\%), SDS (0.1\%), PMSF (1 mM), Sodium deoxycholate (0.5\%), Glycerol (10 \%)] for 30 minutes at $4^{0} \mathrm{C}$. The extracts were cleared by centrifugation at $12,000 \mathrm{rpm}$ for 30 minutes at $4^{0} \mathrm{C}$.

\section{Protein Expression and Purification:-}

The constructs pET-28a+-N/P were transformed in Codon Plus and BL21 DE3 strains respectively. The primary and secondary cultures were prepared according to standard laboratory protocols using suitable antibiotics (for $\mathrm{N}$ protein final concentration of kanamycin and chloramphenicol used were $30 \mu \mathrm{g} / \mathrm{ml}$ and $20 \mu \mathrm{g} / \mathrm{ml}$ respectively; for P protein final concentration of kanamycin used was $30 \mu \mathrm{g} / \mathrm{ml}$ ). Following that it was induced with IPTG (working concentration: $0.1-0.2 \mathrm{mM}$ ) and kept in shaker incubator at $220 \mathrm{rpm}$. For $\mathrm{N}$ protein it was kept at $12^{0} \mathrm{C}$ for $15-16$ hours, whereas for $\mathrm{P}$ protein it was kept at $30^{\circ} \mathrm{C}$ for $8-10$ hours. After incubation the culture was centrifuged at 7,500 rpm for 12 minutes at $4^{0} \mathrm{C}$.The pellet was collected and re-suspended in buffer (per $1 \mathrm{~g}$ pellet, $6 \mathrm{ml}$ of buffer was added; composition of resuspension buffer is given below) by incubating a $37^{0} \mathrm{C}$ for 30 minutes in water bath. The cell suspension was subjected to sonication $(20 \mathrm{kHz}$ with 30 seconds pulse and 1 minute rest for five times). This was centrifuged for 30 minutes at $4^{0} \mathrm{C}$ at $12.000 \mathrm{rpm}$. The supernatant was collected in a fresh Falcon tube. TheHistagged proteins were affinity purified using Ni-NTA agarose beads. This was followed by gel filtration in Sephacryl $^{\mathrm{TM}}$ S-200 HR Column. The protein was further concentrated up to $2 \mathrm{ml}$ in centricon, quantitated by Bradford Assay and electrophoresed on 10\% SDS PAGE to check its quality. The buffer composition was as follows: re-suspension buffer $(25 \mathrm{mM}$ Tris $\mathrm{pH} 8,250 \mathrm{mM}$ sodium chloride, 3mM beta-mercaptoethanol, $5 \%$ glycerol, $0.1 \%$ Triton-X 100, 1mM PMSF), equilibration buffer ( $25 \mathrm{mM}$ Tris $\mathrm{pH} 8,250 \mathrm{mM}$ sodium chloride, $3 \mathrm{mM}$ betamercaptoethanol), wash buffer(25mMTris $\mathrm{pH} 8,250 \mathrm{mM}$ sodium choloride, 3mM beta-mercaptoethanol, $50 \mathrm{mM}$ imidazole) and elution buffer (25mMTris $\mathrm{pH} 8,250 \mathrm{mM}$ sodium choloride, $3 \mathrm{mM}$ beta-mercaptoethanol, $500 \mathrm{mM}$ imidazole ).

\section{Pull Down Assay:-}

$50 \mu \mathrm{l}$ of Protein G beads were taken in a microfuge tube and washed with 1X PBS. 5-10 $\mu \mathrm{g}$ of anti-N/ anti-P antibody was incubated for 30 mins at $4^{0} \mathrm{C}$ with the beads in presence of $1 \mathrm{X}$ PBS and $0.2 \%$ Tween 20. 5-10 $\mu \mathrm{g}$ of purified protein (Nucleocapsid protein / Phosphoprotein) was incubated with antibody coated beads for $1 \mathrm{hr}$ at $4^{0} \mathrm{C}$. Again this was incubated for $2 \mathrm{hrs}$ at $4^{0} \mathrm{C}$ with pre-cleansed cell lysate. Washing was done with $1 \mathrm{X}$ PBS. Elution 
was done with a buffer having high salt concentration $(800 \mathrm{mM} \mathrm{NaCl})$. The eluate was analyzed by SDS PAGE after removing salt by gel filtration. The corresponding bands were trypnized and submitted for MALDI-TOF Analysis

Semi-Quantitative Real Time PCR:-

Semi-quantitative real time PCR was carried out according to the protocol as reported earlier ${ }^{12}$. For this study the oligonucleotides used are listed below in Table 1.

Table 1:- The oligonucleotides used in our study are listed below

\begin{tabular}{|l|l|l|}
\hline Name of Gene & Forward Primer $\left(5^{\prime}-3^{\prime}\right)$ & Reverse Primer $\left(5^{\prime}{ }^{\prime} 3^{\prime}\right)$ \\
\hline Bcl-2 & CTGCACCTGACGCCCTTCACC & CACATGACCCCACCGAACTCAAAGA \\
\hline Bcl-xL & GATCCCCATGGCAGCAGTAAAGCAAG & CCCCATCCCGGAAGAGTTCATTCACT \\
\hline cdc 42 & AGGCTGTCAAGTATGTGGAG & ACAGAGGTTGCTCTAAGGTG \\
\hline RhoA & GCAGGTAGAGTTGGCTTTATGG & CTTGTGTGCTCATCATTCCGA \\
\hline
\end{tabular}

\section{Results:-}

Protein Expression and Purification:-

The purified proteins were analyzed by SDS PAGE. For N protein a sharp band was observed at $60 \mathrm{kD}$. For P protein two bands were observed between 50-60 kD. P protein contains 32 proline residues, as a consequence during migration this protein attain different structural forms. This may be the reason of getting two bands in gel. The bands of interest were excised, trypsinized and submitted for mass analysis. Peptide mass fingerprints generated by MALDI-TOF and the identity of respective proteins were established by comparing the fragments with information available in Mascot database (Fig. 1,2). Protein concentration was estimated by Bradford assay. The concentration of $\mathrm{N}$ protein was $1.7 \mu \mathrm{g} / \mu \mathrm{l}$ and that of $\mathrm{P}$ was $2.4 \mu \mathrm{g} / \mu \mathrm{l}$. Best expressions of $\mathrm{N}$ and $\mathrm{P}$ proteins were obtained at $12^{0} \mathrm{C}$ and $30^{\circ} \mathrm{C}$ with an incubation period of 16 and 8 hours respectively after $0.2 \mathrm{mM}$ IPTG induction.

Finding potential interacting partners for the viral $\mathbf{N}$ and $\mathbf{P}$ proteins by pull down assay:-

To detect the interacting partners of $\mathrm{N}$ and $\mathrm{P}$ proteins we conducted pull down assay experiment separately and visualized the binding proteins on SDS PAGE (Fig. 3A, B). The corresponding bands were separated, trypsinized and submitted for MALDI-TOF Analysis. The probable interaction partners found after Mascot search are presented in Fig. 3C.The binding partners identified for $\mathrm{N}$ were cholinergic receptor, protein tyrosine kinase 2 , hCG, Ig $\gamma 2$ heavy chain, mutant cardiac troponin I, and voltage operated calcium channel. The binding partners identified for $\mathrm{P}$ protein were KLHL23 protein, PI3k, anti-streptococcal/ anti-lysoganglioside Ig heavy chain, potassium voltage gated channel, adaptor related protein complex, and SH2 domain containing protein.

Analysis of expression of downstream molecules of the respective signaling pathway with which $\mathbf{N}$ and $\mathbf{P}$ may interact:-

Only one interacting partner for each of $\mathrm{N}$ and $\mathrm{P}$ proteins was chosen -protein tyrosine kinase 2 (PTK2) for $\mathrm{N}$ protein and phosphatidylinositol 3 kinase (PI3P) for P protein. The expression of certain GTPases like RhoA and cdc42 is regulated by PTK2. The expression of these GTPases at mRNA level was checked by quantitative real time PCR in N expressing cells, taking pcDNA vector transfected cells as control. It has been reported that the gene expressions of these GTPases were up regulated in cancer cells. The expressions of anti-apoptotic genes like Bcl-2 and Bcl-xL at mRNA level was also checked by quantitative real time PCR. Both were found to be increased significantly in P-expressing cells as compared to the vector (pcDNA) transfected cells. PI3K/Akt pathway modulates the expression of anti-apoptotic genes (Fig. 4A, B).

All statistical analysis was performed by using GraphPad Prism. For unpaired student's t test a value was considered significant when $\mathrm{p}<0.05$. The experiments were done in triplicate. 
A)
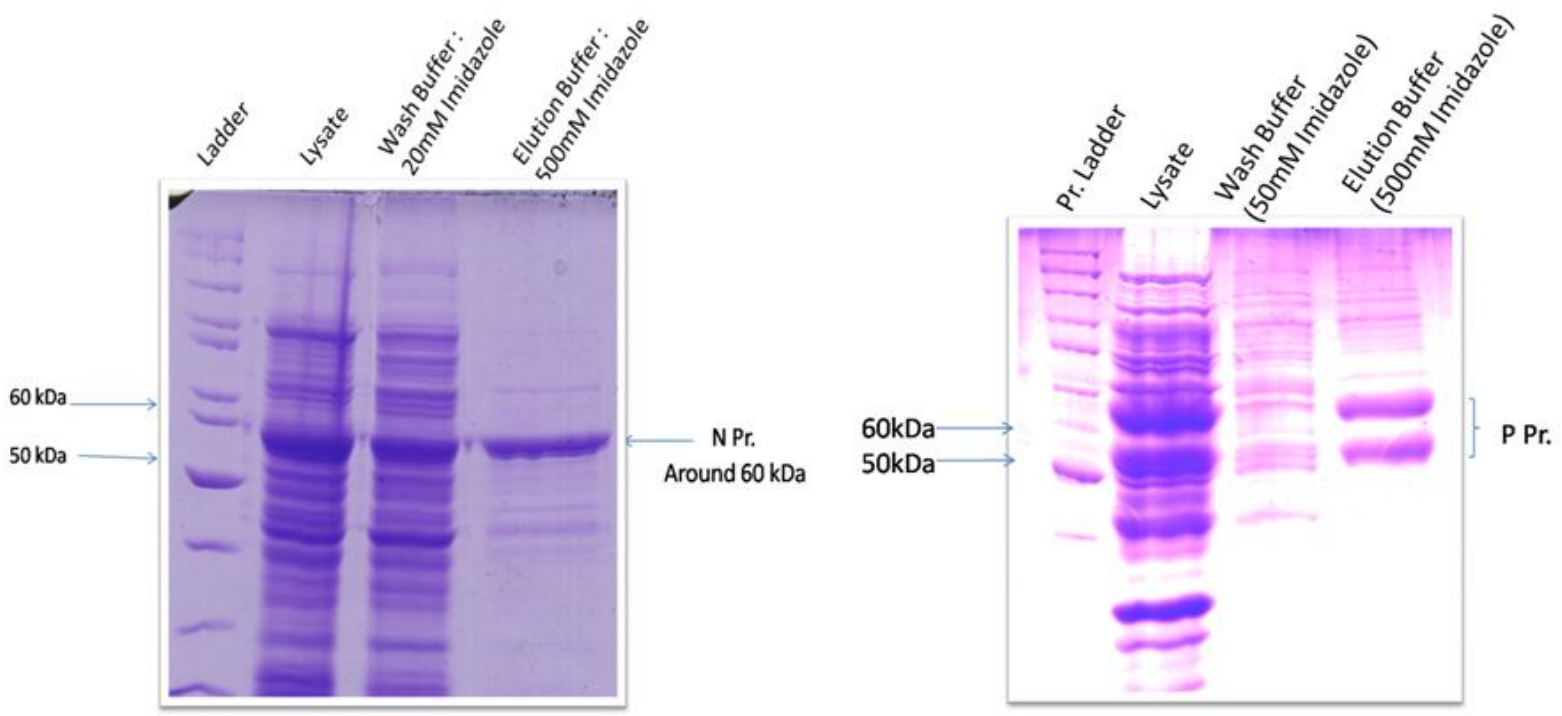

Figure 1:-Protein Purification.(A) N protein purification by Ni-NTA Column. (B) P protein purification by Ni-NTA Column. After IPTG induction at the $12^{\circ} \mathrm{C}$ for $\mathrm{N}$ protein and $30^{\circ} \mathrm{C}$ for $\mathrm{P}$ protein, the bacterial cell pellet was collected by centrifugation, re-suspended in lysis buffer, sonicated and centrifuged. The supernatant was collected and passed through Ni-NTA Column for affinity purification of his-tagged proteins.

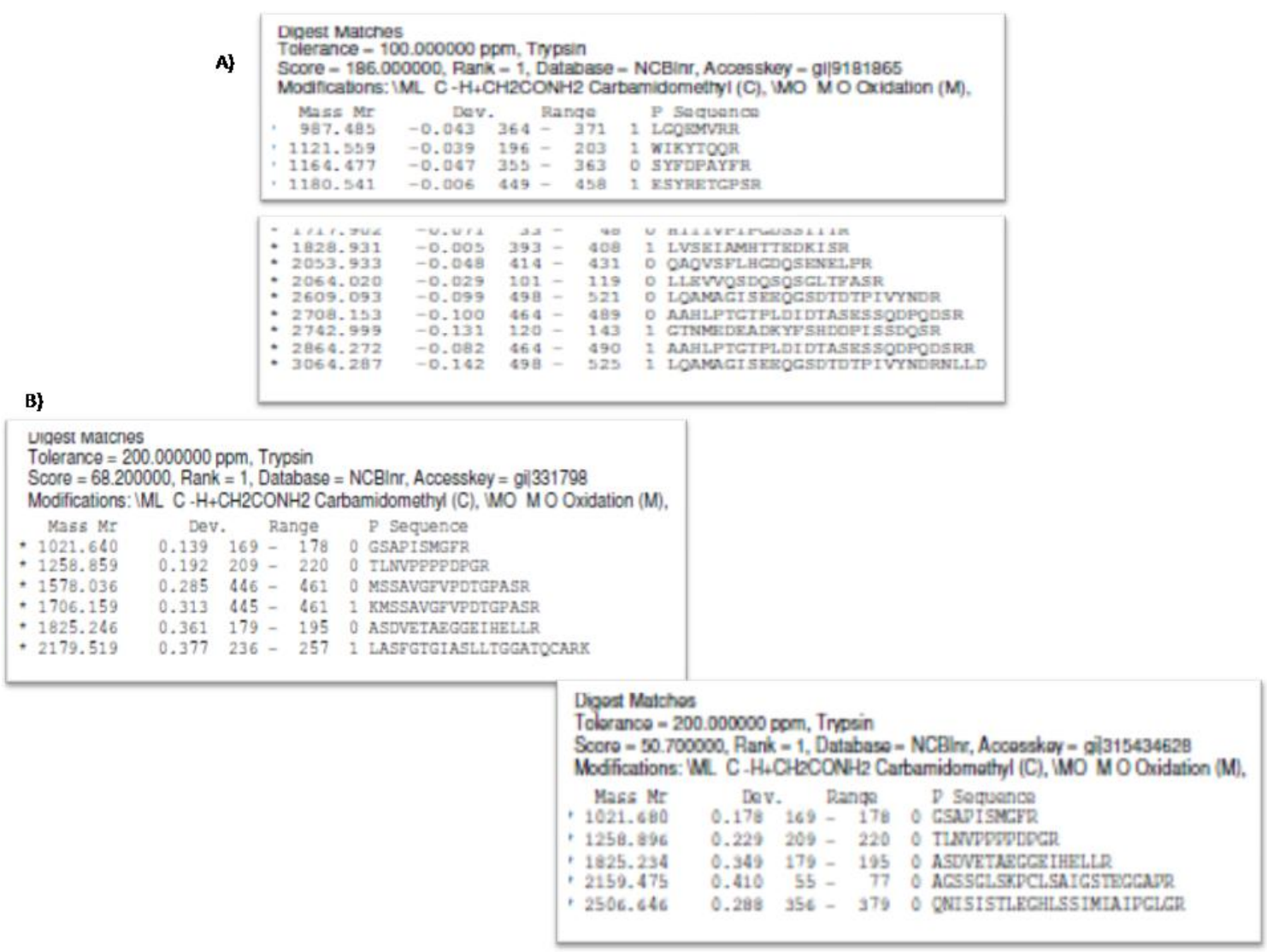

Figure 2:-Mass Analysis. (A) List of peaks and peptide matches for N protein and (B) List of peaks and peptide matches for P protein (Samples 1 and 2) obtained by MALDI-TOF Analysis. 
A)

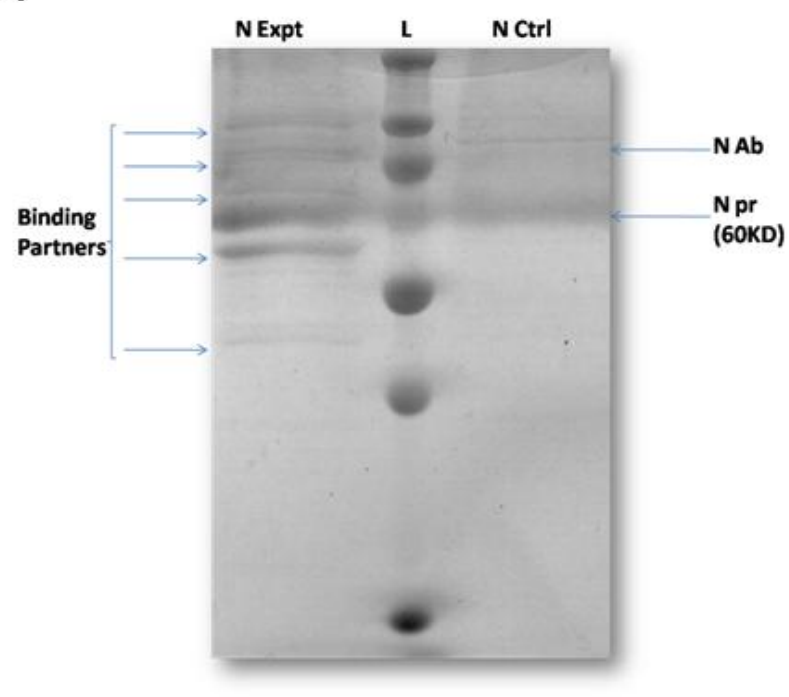

B)

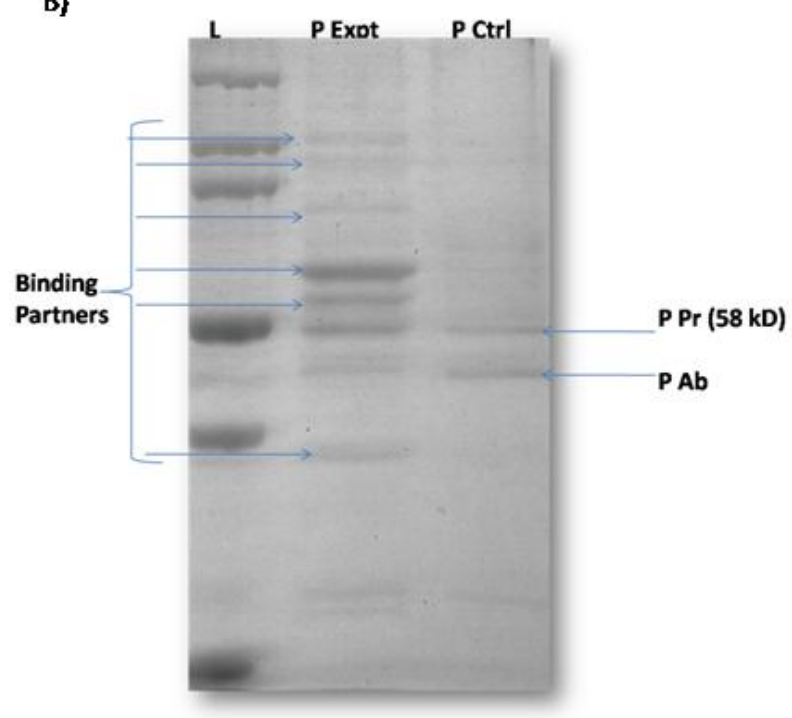

c)

\begin{tabular}{|c|c|}
\hline NPr. Bìnding Partners & P Pr. Binding Partners \\
\hline 1. Cholinergic Receptor & 1. MHLZ3 Protein \\
\hline 2. Probin Tyosine Krase 2 & 2. Phosphetidy inosilnd Bhingse \\
\hline 3. hCG & $\begin{array}{l}\text { 3. Anti-streptococol/ anti- } \\
\text { hsogangliosideinmumoglobuln heary } \\
\text { chain }\end{array}$ \\
\hline $\begin{array}{l}\text { 4. Immumoglobilin gamma } 2 \text { heay } \\
\text { chain }\end{array}$ & 4. Potassium voltage gated channed \\
\hline 5. Mutant Cardiac Troponin I & 5. Allaptor related protein complex \\
\hline 6. Voltage Operated Cakium Channel & 6. SH2 domain containing protein \\
\hline
\end{tabular}

Figure 3:-Pull Down Assay. (A) Binding partners for N protein. (B) Binding partners of P protein. (C) A list of Nand $\mathrm{P}$-interacting proteins as deduced following Pull down assay and MALDI-TOF analysis of the eluted proteins.

A)

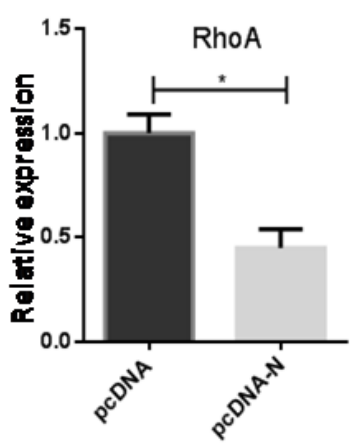

B)

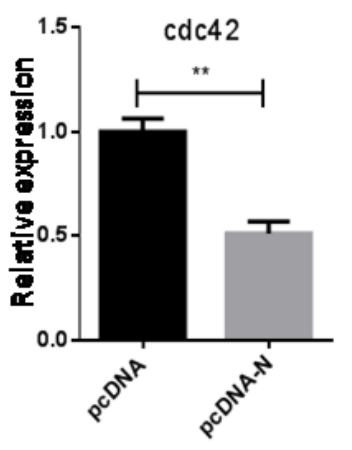

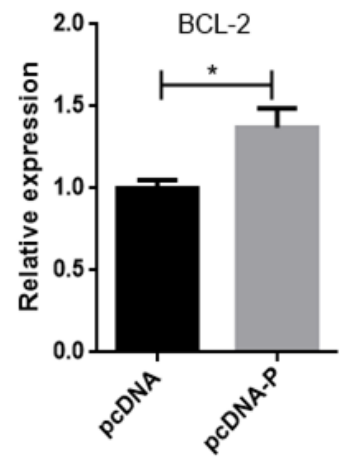

$\mathrm{Bcl}-\mathrm{xL}$

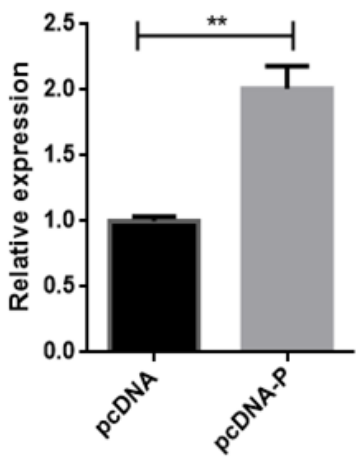

Figure. 4:-Quantitative Real Time PCR.(A) mRNA expression levels of cdc42 and RhoA were diminished in cells expressing N protein. (B) mRNA expression levels of both Bcl-2 and Bcl-xL were increased significantly in cells expressing $\mathrm{P}$. 


\section{Discussion:-}

PTK2 gene product is protein tyrosine kinase 2 (PTK2) is also known as focal adhesion kinase (FAK) ${ }^{13}$. It plays a vital role in celular adhesion. When PTK2 is blocked, the cells become less motile and consequently less metastatic $^{14}$. Structurally this protein contains the C-terminal domain, the N-terminal domain and a catalytic/regulatory domain. The C-terminal domain, consisting of 159 amino acids, targets this protein to focal adhesions. This moiety contains four alpha helices that are reported to be arranged in bundle and is associated with signal transduction ${ }^{14,15}$. The N-terminal domain suppresses the signaling process of PTK2 by preventing the activation of kinase domain. This prevention of activation occurs due to hydrophobic interaction between N-terminal domain and kinase domain ${ }^{16}$. The catalytic domain is located between amino and carboxy terminal domains. Within this kinase domain the activation loop is phosphorylated to ensure the kinase activity of PKT2 ${ }^{17}$. This signaling pathway is associated with apoptosis and celular migration. When PKT2 is overexpressed, apoptosis is inhibited and the prevalence of metastatic tumor is increased ${ }^{18,19}$.

The cell adhesion to the extra cellular matrix (ECM) components is mediated by integrin family of cell surface receptors. Here a signaling cascade is initiated; this organizes the actin cytoskeleton and alters gene expression. PTK2 is reported to be associated with integrin signaling. Graf, a new member of the GTPase activating protein (GAP) family of GTPase regulator interacts with the C-terminal domain of PTK2 to stimulate the GTPase activity of the GTP binding proteins Cdc42 and RhoA. Graf may mediate crosstalk between PTK2 and the Rho family GTPase to control signaling events ${ }^{20}$.

Here the mRNA expression levels of Cdc42 and RhoA were studied by quantitative real time PCR. It was found that mRNA expression levels of both Cdc42 and RhoA were decreased when N protein was expressed in Heal cells compared to the vector (pcDNA) transfected cells. Both Cdc42 and RhoA were reported to be over expressed in many types of cancers. The interaction of $\mathrm{N}$ with PTK2 might suppress the expression of these GTPases to check cancer progression.

The Akt/ PI3K signaling pathway is associated with cell growth, survival, proliferation and migration. The major proteins involved here are phosphatidylinositol 3-kinase (PI3K) and protein kinase B (Akt). Any stimulation by external growth factors activates cell surface receptors and consequently phosphorylation of PI3K. The latter activates plasma membrane lipids to form a second messenger named phosphatidylinositol $(3$, 4, 5) triphosphate (PIP3). Following this recruitment of Akt, a serine/threonine kinase, to the plasma membrane occurs and subsequently downstream processes are initiated ${ }^{21,22}$.

The Akt/ PI3KPathway suppresses some transcription factors inside the nucleus to enhance the transcription of antiapoptotic genes, as for example the Fork head family transcription factors (FoxO/ FH) ${ }^{23}{ }^{24}$. Toensure expression of pro-survival genes it also acts as positive regulator of some transcription factors. It phosphorylates and thus activates IKK $\alpha$ thereby causing degradation of I $\mathrm{B}$ and subsequently nuclear translocation of NF $\mathrm{B}$ occurs. This increases expression of caspase inhibitors like Bcl-xL and $\mathrm{cMyb}^{25,26}$. It also phosphorylates cAMP response element binding protein (CREB) at Ser133, stimulating recruitment of CREB2-binding protein (CBP) and Bcl-2, to the promoter of target genes ${ }^{27}$.It is also a negative regulator of pro-apoptotic proteins. The phosphorylation of the Bcl-2 family member, BAD, on Ser136 causes its translocation from the mitochondrial membrane to the cytosol. There it is sequestered by 14-3-3 proteins (a family of conserved regulatory molecules, expressed in all eukaryotic cells) ${ }^{25}$. This pathway is reported to promote G1-Sphase cell cycle progression by phosphorylating glycogen synthase kinase 3 (GSK3) at Ser9. This phophorylation causes an inactivation of the molecule thereby preventing the phosphorylation and degradation of cyclin D1.It also promotes cell migration by establishing interactions with cytoskeleton components. It phosphorylates vimentin at Ser39, thereby preventing its degradation. The activation of Akt is associated with malignancy ${ }^{28}$.

Here the mRNA expression levels of two anti-apoptotic genes (Bcl-2 and Bcl-xL) were studied. It was found that the expression levels of anti-apoptotic genes were increased and that of pro-apoptotic gene was decreased. Therefore it might be concluded that $\mathrm{P}$ protein might interact with PI3K/Akt pathway to enhance proliferation in HeLa cells. The study presents an example of interaction and presumably co-evolution of viral molecules vis-à-vishost cell molecules and formation of regulatory circuits. The results open up new vistas for inquiry as to how measles virus $\mathrm{N}$ protein could modulate important physiological functions of the host via their interaction with cholinergic receptor, hCG, mutant cardiac troponin and voltage operated calcium channel. Similarly physiological consequence of viral P protein interaction with PI3K, anti-streptococcal immunoglobulin heavy chain and voltage-gated potassium channel 
remain to be studied with reference to the bearing they may have on pathogenesis. It is clear that $\mathrm{N}$ and $\mathrm{P}$ proteins have contrasting effects on expression of pro- and anti-apoptotic molecules.

\section{Acknowledgement:-}

We are thankful to Prof. Martin Billeter for providing the plasmids.We thank Dean, SLS for providing access to the central instruments facility. SB is recipient of research fellowships from UGC and DST-PURSE.

\section{Author Contributions:-}

Concept and experimental design: SB PKY; execution of experiments: SB RKJ; Data analysis: SB PKY; Procurement of reagents/materials/analysis tools: SB PKY. Preparation of manuscript: SB PKY.

\section{References:-}

1. Egelman EH, Wu SS, Amrein M, Portner A, Murti G. The Sendai virus nucleocapsid exists in at least four different helical states. J Virol. 1989; 63(5): 2233-2243.

2. Karlin D, Longhi S, Canard B. Substitution of two residues in the measles virus nucleoprotein results in an impaired self-association. Virology. 2002; 302(2): 420-432.

3. Bankamp B, Horikami SM, Thompson PD, Huber M, Billeter M, Moyer SA. Domains of the measles virus N protein required for binding to P protein and self-assembly. Virology 1996; 216(1): 272-277.

4. Zhang X, Glendening C, Linke H., Parks CL, Brooks C, Udem SA, Oglesbee M. Identification and characterization of a regulatory domain on the carboxyl terminus of the measles virus nucleocapsid protein. $\mathrm{J}$ Virol. 2002; 76(17): 8737-8746.

5. Zhang G, Zhong Y, Qin Y, Chen M. Interaction of human parainfluenza virus type 3 nucleoprotein with matrix protein mediates internal viral protein assembly. J. Virol. 2016; 90(5): 2306-2315.

6. TenOever BR, Servant MJ, Grandvaux N, Lin R, Hiscott J. Recognition of the measles virus nucleocapsid as a mechanism of IRF-3 activation. J Virol. 2002; 76(12): 3659-3669.

7. Laine D, Bourhis JM, Longhi S, Flacher M, Cassard L, Canard B, Sautes-Fridman C, Rabourdin-Combe C, Valentin $\mathrm{H}$. Measles virus nucleoprotein induces cell-proliferation arrest and apoptosis through NTAIL-NR and NCORE-FcgammaRIIB1 interactions, respectively. J Gen Virol. 2005; 86(Pt 6): 1771-1784.

8. Devaux P, von Messling V, Songsungthong W, Springfeld C, Cattaneo R. Tyrosine 110 in the measles virus P protein is required to block STAT1 phosphorylation. Virology. 2007; 360(1): 72-83.

9. Yokota S, Okabayashi T, Yokosawa N, Fujii N. Measles virus P protein suppresses Toll-like receptor signal through up-regulation of ubiquitin-modifying enzyme A20. FASEB J. 2008; 22(1): 74-83.

10. Caignard G, Guerbois M, Labernardiere JL, Jacob Y, Jones LM, Wild F, Tangy F, VidalainPO.Measles virus V protein blocks Jak1-mediated phosphorylation of STAT1 to escape IFN-alpha/beta signaling. Virology. 2007; 368(2): 351-362.

11. Bhaskar, A., Bala, J., Varshney, A., Yadava, P. Expression of measles virus nucleoprotein induces apoptosis and modulates diverse functional proteins in cultured mammalian cells. PLoS One. 2011; 6(4): e18765.

12. Jaiswal RK, Kumar P, Sharma A, Mishra DK, Yadava PK. Proteomic identification of proteins differentially expressed following overexpression of hTERT (human telomerase reverse transcriptase) in cancer cells.Plos One. 2017; 12(7): e0181027.

13. André E, BeckerAndré M. Expression of an $\mathrm{N}$-terminally truncated form of human focal adhesion kinase in brain. Biochemical and Biophysical Research Communications. 1993; 190(1): 140-147.

14. Blackshaw SE, Dow JK, Lackie JM. The dictionary of cell and molecular biology (3rd ed.). San Diego: Academic Press. 1999. ISBN 0124325653.

15. Hildebrand JD, Schaller MD, Parsons JT. Identification of sequences required for the efficient localization of the focal adhesion kinase, pp125FAK, to cellular focal adhesions. The Journal of Cell Biology. 1993; 123(4): 993-1005.

16. Hildebrand JD, Schaller MD, Parsons JT. Paxillin, a tyrosine phosphorylated focal adhesionassociated protein binds to the carboxyl terminal domain of focal adhesion kinase. Molecular Biology of the Cell. 1995; 6(6): 637647.

17. Lietha D, Cai X, Ceccarelli DF, Li Y, Schaller MD, Eck MJ. Structural basis for the autoinhibition of focal adhesion kinase. Cell. 2007; 129(6):1177-1187. 
18. Calalb MB, Polte TR, Hanks SK. Tyrosine phosphorylation of focal adhesion kinase at sites in the catalytic domain regulates kinase activity: a role for Src family kinases. Molecularand Cellular Biology. 1996; 15(2): 954-963.

19. Mehlen P, Puisieux A. Metastasis: a question of life or death. Nat. Rev.Cancer. 2006; 6(6): 449-458.

20. NdozangueTouriguine O, Hamelin J, Bréard J. Cytoskeleton and apoptosis. Biochem. Pharmacol. 2008; 76(1): $11-18$.

21. Hildebrand JD, Taylor JM, Parsons JT. An SH3 domain containing GTPase activating protein for Rho and Cdc42 associates with focal adhesion kinase. Mol Cell Biol. 1996; 16(6): 3169-3178.

22. Osaki M, Oshimura M, Ito H. The PI3K-Akt pathway: Its functions and alterations in human cancer. Apoptosis. 2004; 9(6): 667-676.

23. Manning BD, Cantley LC. AKT/PKB Signaling: Navigating Downstream. Cell. 2007; 129(7): 1261-1274.

24. Vanhaesebroeck B, Alessi DR. The PI3K-PDK1 connection: more than just a road to PKB. Biochem J. 2000; 346(Pt 3): 561-576.

25. Song G, Ouyang G, Bao S. The activation of Akt/PKB signaling pathway and cell survival. J Cell Mol Med. 2005; 9(1): 59-71.

26. Du K, Montminy M. CREB Is a Regulatory Target for the Protein Kinase Akt/PKB. J Biol Chem. 1998; 273(49): 32377-32379.

27. Alao JP. The regulation of cyclin D1degradation: roles in cancer development and the potential for therapeutic invention. Molecular Cancer. 2007; 6: 24.

28. Hay N, Sonenberg N. Upstream and downstream of mTOR. Genes Dev. 2004; 18(16): 1926-1945. 